\title{
KONTRIBUSI SEKTOR PARIWISATA TERHADAP PENDAPATAN ASLI DAERAH KABUPATEN JEMBER TAHUN 2011-2017
}

\author{
Fawaidul Khoir, Hety Mutika Ani, Wiwin Hartanto \\ ${ }^{1}$ Program Studi Pendidikan Ekonomi, Fakultas Keguruan dan Ilmu Pendidikan, Universitas Jember \\ E-mail: Fawaidulkhoir0201@gmail.com
}

\begin{abstract}
Abstrak
Sektor pariwisata merupakan salah satu penunjang Pendapatan Asli Daerah (PAD) di Kabupaten Jember. Tahun 2008 Kabupaten Jember menerapkan pengembangan tiga sektor salah satunya adalah sektor pariwisata. Pengembangan sektor pariwisata bertujuan untuk meningkatkan perekonomian yang akan berdampak pada Pendapatan Asli Daerah. Tujuan dari penelitian ini adalah untuk mengetahui besarnya kontribusi sektor pariwisata terhadap Pendapatan Asli Daerah Kabupaten Jember pada tahun 2011-2017, melihat trend pendapatan dan ramalan pendapatan sektor pariwisata pada tahun-tahun selanjutnya. Penelitian ini merupakan penelitian analisis deskriptif kuantitatif. Penentuan daerah penelitian menggunakan metode purposive area. Hasil analisis kontribusi pada penelitian ini menunjukkan kontribusi sektor pariwisata terhadap PAD yang setiap tahunnya mengalami fluktuatif, meskipun setiap tahunnya pendapatan dari sektor pariwisata selalu mengalami kenaikan. Kontribusi terbesar terdapat pada tahun 2011 yaitu sebesar $3,96 \%$. Kontribusi terbesar ini disebabkan karena pendapatan sektor pariwisata dari penerimaan retribusi tempat parkir khusus cukup besar serta kecilnya peningkatan penerimaan sektor-sektor PAD lainnya yang sah dibandingkan dengan tahun sebelumnya. Sedangkan untuk kontribusi terendah terdapat pada tahun 2017 yaitu sebesar $2,87 \%$. Penurunan ini disebabkan karena peningkatan penerimaan dari sumber Lain-Lain Pendapatan Daerah yang Sah yang sangat tinggi. Sehingga menyebabkan kontribusi sektor pariwisata sangat kecil meskipun total pendapatan dari sektor pariwisata sendiri mengalami kenaikan dibandingkan dengan tahun sebelumnya. Hasil analisis selanjutnya yaitu analisis trend yang menunjukkan ramalan pendapatan pada tahun-tahun selanjutnya akan terus meningkat. Ramalan pendapatan sektor pariwisata Kabupaten Jember pada tahun 2018 sekitar 24,6 M dan akan terus meningkat di tahun-tahun berikutnya.
\end{abstract}

Kata Kunci: Sektor Pariwisata, Kontribusi, Pendapatan Asli Daerah

\section{PENDAHULUAN}

Pembangunan ekonomi merupakan hal mutlak yang harus dilakukan oleh suatu daerah untuk meningkatkan kesejahteraan dan taraf hidup masyarakatnya. Dalam prakteknya pembangunan ekonomi dapat dilakukan melalui berbagai bidang kehidupan, seperti bidang ekonomi, pertahanan dan keamanan, politik, lingkungan hidup, sosial dan budaya (Frisdiantara, 2016:1). Pembangunan perekonomian juga dapat dilakukan dengan memanfaatkan sumber daya yang dimiliki oleh masing-masing daerah secara maksimal tanpa mengurangi perhatian pada kekayaan lingkungan dan kesejahteraan masyarakat sekitar. Pemanfaatan sumber daya diharapkan meningkatkan pertumbuhan ekonomi yang nantinya akan berdampak pada pendapatan daerah tersebut.

Pendapatan daerah di suatu wilayah berbeda-beda, ini ditinjau dari seberapa besar kekayaan sumber daya yang dimiliki daerah tersebut dan optimalisasi pengelolaannya. Menurut Adisasmita (2011:144) sumber-sumber penerimaan daerah dalam pelaksanaan desentralisasi salah satunya adalah Pendapatan Asli Daerah (PAD). Menurut Undang-Undang No. 33 Tahun 2004, Pendapatan Asli Daerah terdiri dari pajak daerah, retribusi daerah, hasil perusahaan milik daerah, dan hasil pengelolaan kekayaan daerah yang dipisahkan serta pendapatan lain-lain yang sah.

Pendapatan dari sumber-sumber PAD akan tinggi jika pengelolaan sumber-sumber tersebut dikelola dengan maksimal. Pengelolaan sumber-sumber PAD dapat dilakukan dengan mengoptimalkan sektor basis yang ada didaerah tersebut. Sektor basis merupakan sektor yang potensial untuk dikembangkan guna mendukung pertumbuhan perekonomian suatu wilayah. Adanya sektor basis disuatu daerah maka akan memberikan keuntungan pada arus perekonomian dan akan menciptakan pertumbuhan ekonomi yang pesat.

Pariwisata merupakan salah satu sektor basis yang dapat di maksimalkan. Pariwisata merupakan salah 
satu sektor penunjang pendapatan suatu daerah. Oleh karena itu pengembangan pariwisata terus dilakukan oleh pemerintah untuk meningkatkan pendapatan sekaligus memaksimalkan potensi yang ada di daerah tersebut. Sejak tahun 1978 pemerintah terus berusaha mengembangkan kepariwisataan di Indonesia. Pariwisata perlu ditingkatkan dan diperluas untuk meningkatkan penerimaan devisa, dan memperkenalkan kebudayaan (TAP MPR No. IV/MPR/1978). Pembinaan maupun pengembangan pariwisata dilakukan dengan tetap memperhatikan pelestarian budaya serta kepribadian nasional (Widyastuti dkk, 2017:1). Bentuk lain dari keseriusan pengembangan kepariwisataan diseluruh wilayah Indonesia oleh pemerintah yaitu dengan membuat Peraturan Pemerintah, Keputusan Presiden, Undang-Undang dan peraturan lainnya yang berkaitan dengan pengembangan kepariwisataan. Salah satu dari peraturan tersebut yaitu Undang-Undang No. 10 Tahun 2009 tentang Kepariwisataan.

Menurut Wardiyanta (2006:50) pariwisata merupakan sumber daya yang penting bagi daerah yang menjadi tempat tujuan wisata. Pariwisata dapat menjadi sumber pemasukan uang dari daerah lain dengan sedikit dampak lingkungan. Pariwisata dapat menjadi sumber daya untuk melaksanakan upaya pemeliharaan/preservasi berbagai hasil budaya masa lampau. Sebagai sumber daya pariwisata perlu dikelola dengan tepat supaya pengembangannya tidak menjadi sumber kerusakan atau sumber bencana. Keuntungan adanya pengembangan pariwisata menurut Sulaiman (2013:138) sebagai berikut;

1. Membuka kesempatan kerja;

2. Menambah pemasukan/pendapatan masyarakat atau daerah;

3. Merangsang pertubuhan kebudayaan asli Indonesia;

4. Menunjang gerak pembangunan daerah.

Perkembangan pariwisata setiap tahunnya mengalami peningkatan, berbagai daerah memiliki tempat wisata yang beragam dan unik, mulai dari yang berskala nasional maupun internasional. Indonesia memiliki banyak sekali tempat wisata dan berbagai kebudayaan yang unik dimata dunia. Salah satu kabupaten dengan destinasi wisata di Indonesia ialah Kabupaten Jember. Kabupaten Jember adalah daerah yang memiliki beberapa sektor PDRB (Produk Domestik Regional Bruto), diataranya;

1. Pertanian, Perkebunan, Kehutanan dan Perikanan

2. Pertambangan dan Penggalian

3. Industri Pengolahan

4. Listrik, Gas dan Air Bersih

5. Bangunan

6. Perdagangan, Hotel dan Restoran

7. Pengangkutan dan Komunikasi

8. Keuangan, Persewaan dan Jasa Perusahaan

9. Jasa Kesenian, Hiburan, Rekreasi dan Jasa Kegiatan Lainnya.

Salah satu sektor unggulan tersebut adalah pariwisata yang berkaitan dengan Hotel, Restoran, Kesenian, Hiburan dan Rekreasi.

Pengembangan pariwisata di Kabupaten Jember dapat dikatakan cukup pesat. Hal ini sesuai dengan pembangunan Kabupaten Jember yang memprioritaskan tiga sektor yaitu sektor pertanian, perikanan dan pariwisata (Bapeda 2008:6). Selain itu pengembangan pariwisata di Kabupaten Jember juga melalui Program Bulan Kerkunjung ke Jember (BBJ). BBJ adalah serangkaian kegiatan wisata olah raga, kuliner dan budaya yang pertama kali dilaksanakan pada tahun 2007. Kabupaten Jember juga merupakan salah satu kabupaten yang dikenal oleh wisatawan lokal maupun asing melalui Jember Fashion Carnaval (JFC). JFC adalah event busana pertama di Indonesia yang sudah diselenggarakan selama 16 tahun dan event tersebut sudah dikenal oleh dunia fashion Internasional. Menurut Hermawan dan Sapta Nirwandar dalam buku Tourism Marketing 3.0 (2013:73) menyebutkan bahwa JFC menjadi salah satu dari 7 karnaval terbesar di dunia. JFC juga disandingkan dengan karnaval Mardi Gras di Amerika Serikat yang berlangsung 200 tahun dan Rio Carnaval di Rio de Janeiro yang sudah terkenal di dunia. Kabupaten Jember juga memiliki objek wisata budaya lain seperti Tanoker, Petik Laut, Festival Pegon Hias dan kesenian Reog.

Perkembangan pariwisata di Kabupaten Jember setiap tahunnya terus meningkat, mulai dari wisata pantai, pegunungan, agro, pemandian, dan budaya begitupula wisatawan yang berkunjung ke Kabupaten 
Jember. Berikut data perkembangan pariwisata Kabupaten Jember;

Tabel 1. Perkembangan Objek Wisata, Hotel dan Wisatawan Kabupaten Jember tahun 2011-2017

\begin{tabular}{ccccc}
\hline \multirow{2}{*}{ Tahun } & $\begin{array}{c}\text { Objek } \\
\text { Wisata }\end{array}$ & Hotel & \multicolumn{3}{c}{ Wisatawan } \\
\cline { 4 - 5 } & 43 & 33 & Mancanegara & Domestik \\
\hline 2011 & 43 & 33 & 923 & 741.688 \\
2012 & 44 & 33 & 1.682 & 740.615 \\
2013 & 44 & 42 & 1.869 & 828.368 \\
2014 & 41 & 41 & 2.672 & 917.528 \\
2015 & 51 & 51 & 3.017 & 1.052 .777 \\
2017 & 65 & 51 & 2.751 & 1.299 .482 \\
\hline
\end{tabular}

Sumber: Badan Pusat Statistik dan Dinas Pariwisata Kab. Jember 2011-2017.

Perkembangan objek wisata, hotel dan wisatawan yang berkunjung ke Kabupaten Jember dapat di tunjukkan pada tabel 1. Kabupaten Jember memiliki potensi yang besar dalam sektor pariwisata, sehingga hal tersebut diprioritaskan oleh Pemerintah Daerah Kabupaten Jember. Pada tahun 2017 Kabupaten Jember memiliki 65 objek wisata dan empat diantaranya dikelola langsung oleh Pemerintah Daerah. Objek wisata tersebut terdiri atas wisata pantai, pegunungan, budaya serta wisata agro. Sedangkan untuk hotel berjumlah 51 hotel, 6 hotel berbintang dan 45 hotel melati. Wisatawan setiap tahunnya meningkat, tercatat pada tahun 2017 wisatawan mancanegara maupun domestik yang berkunjung ke Kabupaten Jember berjumlah 1.994.924 orang.

Perkembangan pariwisata Kabupaten Jember berdampak positif terhadap perekonomian dan memberikan kontribusi yang pasti terhadap Pendapatan Asli Daerah Kabupaten Jember. Kontribusi dapat berupa sumbangan, sokongan atau dukungan terhadap suatu kegiatan. Data perkembangan pendapatan dari sektor pariwisata Kabupaten Jember dapat dilihat pada tabel 2 berikut;

Tabel 1. Pendapatan Dinas Pariwisata Kabupaten Jember 2011-2017

\begin{tabular}{cc}
\hline Tahun & Pendapatan \\
\hline 2011 & 7.234 .391 .072 \\
2012 & 9.517 .896 .662 \\
2013 & 11.573 .002 .599 \\
2014 & 14.381 .226 .334 \\
2015 & 14.551 .481 .334 \\
2016 & 17.879 .924 .324 \\
2017 & 20.620 .899 .872
\end{tabular}

Sumber : Badan Pusat Statistik 2011-2017

Pendapatan Dinas Pariwisata Kabupaten Jember setiap tahunnya mengalami peningkatan dari tahun 2011-2017. Pada tahun 2011 pendapatan dari sektor pariwisata Kabupaten Jember sebesar Rp. 7,2 Miliar, dan pada tahun 2017 tembus Rp. 20,6 miliar. Perkembangan pendapatan dari sektor pariwisata ini sangat pesat, hal ini disebabkan karena pengelolaan pada sektor pariwisata dilakukan semaksimal mungkin oleh pemerintah daerah melalui stakeholders dan dinas yang bersangkutan. Berdasarkan kondisi tersebut, maka peneliti tertarik untuk melakukan penelitian dengan judul "Kontribusi Sektor Pariwisata Terhadap Pendapatan Asli Daerah Kabupaten Jember tahun 2011-2017’.

\section{METODE}

Jenis penelitian ini adalah deskriptif kuantitatif. Penentuan daerah penelitian menggunankan metode porposive area yaitu penelitian dilaksanakan di Kabupaten Jember dengan pertimbangan bahwa Kabupaten Jember memiliki pertumbuhan ekonomi yang relatif tinggi dalam sektor pariwisata, dan mampu dikembangkan berdasarkan sektor unggulan guna meningkatkan Pendapatan Asli Daerah (PAD) Kabupaten Jember serta ketersediaan data yang dibutuhkan oleh peneliti. Data yang dianalisis adalah data sekunder dan metode 
pengumpulan data menggunakan studi dokumentasi. Metode analisis yang digunakan yaitu analisis proporsinalitas untuk melihat berapa besar persentase kontribusi sektor pariwisata terhadap PAD Kabupaten Jember. Rumusnya sebagai berikut:

$$
\text { Kontribusi }(t)=\frac{x 1}{y 1} \times 100 \%
$$

Keterangan :

$\mathrm{t}=$ Kontribusi sektor pariwisata terhadap

total Pendapatan Asli Daerah

$\mathrm{x} 1=$ Total penerimaan sektor pariwisata

y1 = Total Pendapatan Asli Daerah

Selanjutnta yaitu analisis trend yang akan digunakan untuk meramal pendapatan sektor pariwisata pada tahun-tahun selanjutnya. Rumusnya sebagai berikut:

$$
Y^{\prime}=a+b X
$$

$$
\begin{aligned}
& \text { Dimana : } \\
& \begin{aligned}
\mathrm{Y}^{\prime} & =\text { Variabel yang diramalkan } \\
\mathrm{a} & =\text { Konstanta } \\
\mathrm{b} & =\text { Nilai koefisien } \text { trend } \\
\mathrm{X} & =\text { Variabel waktu (Tahun) }
\end{aligned}
\end{aligned}
$$

Nilai Koefisien dan Konstanta trend pendapatan sektor pariwisata dapat dihitung dengan cara berikut;

$$
\mathrm{a}=\frac{\sum \mathrm{Y}}{\mathrm{n}} \quad \mathrm{N}=\text { Jumlah Data } \quad \mathrm{b}=\frac{\sum \mathrm{XY}}{\sum \mathrm{X} 2}
$$

\section{HASIL DAN PEMBAHASAN}

\section{Hasil Penelitian}

Objek wisata di Kabupaten Jember pada tahun 2017 adalah sebanyak 65 objek wisata, yang terdiri atas objek wisata pantai sebanyak 10 , wisata agro 6 , wisata pegunungan 4 , wisata budaya 11 dan sisanya sejumlah 34 objek wisata adalah wisata alam dan wisata buatan. Data jumlah objek wisata di atas diambil oleh peneliti melalui data BPS Kabupaten Jember, namun masih banyak objek wisata di Kabupaten Jember yang belum terdaftar dalam Satuan Kerja Perangkat Daerah (SKPD) terkait.

Objek wisata yang dikelola langsung oleh Pemerintah Daerah Kabupaten Jember melalui Dinas Pariwisata dan Kebudayaan Kabupaten Jember diantaranya:

Tabel 3. Daftar Objek Wisata yang dikelola oleh Pemerintah Daerah Kabupaten Jember.

\begin{tabular}{cll}
\hline No & \multicolumn{1}{c}{ Nama Objek Wisata } & \multicolumn{1}{c}{ Alamat } \\
\hline 1 & Patemon & Desa Patemon \\
2 & Pemandian Rembangan & Desa Kemuning Rejo \\
3 & Pemandian Kebonagung & J1. Arowana 59, Jember \\
4 & Pantai Watu Ulo & Desa Sumber Rejo \\
5 & Pantai Paseban & Desa Paseban \\
6 & Pantai Puger & Desa Puger Kulon \\
\hline
\end{tabular}

Sumber : Dinas Pariwisata Kabupaten Jember, 2017. 
Tabel 3 diatas adalah objek wisata yang dikelola langsung oleh Pemerintah Daerah Kabupaten Jember yang sekaligus memberikan kontribusi terhadap pendapatan sektor pariwisata Kabupaten Jember. Selain itu masih ada beberapa objek wisata yang dapat memberikan penghasilan terhadap Dinas Pariwisata Kabupaten Jember yang dapat melalui pajak dan retribusi diantaranya yaitu tempat menonton film/bioskop, tempat karaoke, tempat permainan (bilyard, golf, dan ketangkasan), pijat refleksi, pemandian uap, pertandingan olahraga dan wisma daerah prajamukti (Dinas Pariwisata Kabupaten Jember, 2017).

Berkembangnya objek wisata di Kabupaten Jember dapat didukung dengan adanya fasilitas yang memadai seperti Hotel, Restoran dan akomodasi lainnya. Hotel merupakan salah satu sarana utama bagi wisatawan untuk bertempat tinggal sementara. Pada tahun 2017 di Kabupaten Jember setidaknya terdapat sekitar 51 hotel yang tersebar di berbagai wilayah. Hotel tersebut terdiri atas 6 hotel berbintang dan 45 hotel melati. Hotel tersebut tentu memberikan pengaruh terhadap perekonomian daerah seperti terhadap PDRB dan PAD Kabupaten Jember. Untuk PAD sendiri, sarana dan prasarana pariwisata seperti hotel ini dapat berkontribusi melalui pembayaran pajak dan retribusi kepada Pemerintah Daerah Kabupaten Jember melalui dinas-dinas terkait. Pada tahun 2017 pendapatan dari subsektor hotel di Kabupaten Jember sebesar 4,6 miliar. Tentu hal tersebut akan memberikan pengaruh terhadap peningkatan PAD Kabupaten Jember.

Perkembangan pendapatan dari sektor pariwisata dalam kurun waktu 2011-2017 selalu mengalami peningkatan. Peningkatan pendapatan pada tahun 2011-2017 tersebut dapat dilihat pada tabel 4 sebagai berikut :

Tabel 4. Perkembangan pendapatan sektor pariwisata Kabupaten Jember tahun 2011-2017.

\begin{tabular}{ccc}
\hline No. & Tahun & Realisasi (Rp) \\
\hline 1. & 2011 & 7.234 .391 .072 \\
2. & 2012 & 9.517 .896 .662 \\
3. & 2013 & 11.573 .002 .599 \\
\hline No. & Tahun & Realisasi (Rp) \\
\hline 4. & 2014 & 14.381 .226 .334 \\
5. & 2015 & 14.551 .481 .334 \\
6. & 2016 & 17.879 .924 .324 \\
7. & 2017 & 20.620 .899 .872 \\
\hline
\end{tabular}

Sumber: Dinas Pariwisata Kabupaten Jember tahun 2011-2017

Pendapatan sektor pariwisata Kabupaten Jember pada tabel 4 diatas adalah pendapatan yang dikelola oleh Dinas Pariwisata dan Kebudayaan Kabupaten Jember, dimana pendapatan dari sektor pariwisata tersebut terdiri atas beberapa subsektor. Subsektor pendapatan tersebut diantaranya yaitu :

1. Pajak yang terdiri atas pajak hotel dan pajak restoran (Rumah Makan, Cafe dan Catering).

2. Pajak Hiburan terdiri atas pajak tontonan film/bioskop dan pagelaran kesenian/musik/tari.

3. Retribusi tempat parkir khusus terdiri atas retribusi parkir pada objek wisata Patemon, Rembangan, Kebonagung dan objek wisata lainnya.

4. Retribusi Tempat Penginapan terdiri atas penginapan/pesanggaran Rembangan, penginapan Kebonagung dll.

5. Retribusi Tempat Rekreasi dan Olah Raga terdiri atas objek wisata Watu Ulo, Patemon, Rembangan (Pemandian), Kebonagung (Pemandian), Pantai Paseban, Pantai Puger dan objek wisata lainnya yang ada di dalam daftar SKPD Kabupaten Jember.

Berikut hasil analisis proporsionalitas kontribusi sektor pariwisata terhadap Pendapatan Asli Daerah Kabupaten Jember tahun 2011-2017, setelah dilakukan analisis data oleh peneliti, data tersebut dijabarkan pada tabel 5 sebagai berikut :

Tabel 5. Persentase Kontribusi Sektor Pariwisata Terhadap Pendapatan Asli Daerah Kabupaten Jember tahun 2011-2017.

\begin{tabular}{llccc}
\hline \multirow{2}{*}{ No } & Tahun & $\begin{array}{c}\text { Pendapatan Sektor } \\
\text { Pariwisata (Rp) }\end{array}$ & Pendapatan Asli Daerah (Rp) & Kontribusi \\
\hline 1 & 2011 & 7.234 .391 .072 & 182.797 .340 .158 & $3,96 \%$ \\
2 & 2012 & 9.517 .896 .662 & 255.804 .775 .083 & $3,72 \%$ \\
3 & 2013 & 11.573 .002 .599 & 308.383 .350 .304 & $3,75 \%$ \\
4 & 2014 & 14.381 .226 .334 & 441.605 .617 .222 & $3,26 \%$ \\
\hline
\end{tabular}




\begin{tabular}{lllll}
\hline 5 & 2015 & 14.551 .481 .334 & 462.457 .671 .769 & $3,15 \%$ \\
6 & 2016 & 17.879 .924 .324 & 524.137 .897 .016 & $3,41 \%$ \\
7 & 2017 & 20.620 .899 .872 & 719.105 .671 .347 & $2,87 \%$ \\
\hline
\end{tabular}

Sumber : Data Diolah, 2018

Selajutnya yaitu analisis trend yang digunakan untuk meramal pendapatan sektor pariwisata pada tahuntahun selanjutnya. Hasil analisis trend sebagai berikut:

Tabel 6 Perhitungan Trend Perkembangan Pendapatan Sektor Pariwisata Kabupaten Jember tahun 2011-2024

\begin{tabular}{cccc}
\hline No & Tahun & $\mathbf{X}$ & $\mathbf{Y}^{\prime}=\mathbf{1 3 . 6 7 9 . 8 3 1 . 7 4 2 + ( 2 . 1 3 7 . 9 3 0 . 7 3 1 \times \mathbf { X } )}$ \\
\hline 1 & 2011 & -3 & 7.266 .039 .550 \\
2 & 2012 & -2 & 9.403 .970 .281 \\
3 & 2013 & -1 & 11.541 .901 .011 \\
4 & 2014 & 0 & 13.679 .831 .742 \\
5 & 2015 & 1 & 15.817 .762 .473 \\
6 & 2016 & 2 & 17.955 .693 .203 \\
7 & 2017 & 3 & 20.093 .623 .934 \\
$\mathbf{8}$ & $\mathbf{2 0 1 8}$ & $\mathbf{4}$ & $\mathbf{2 2 . 2 3 1 . 5 5 4 . 6 6 5}$ \\
$\mathbf{9}$ & $\mathbf{2 0 1 9}$ & $\mathbf{5}$ & $\mathbf{2 4 . 3 6 9 . 4 8 5 . 3 9 5}$ \\
$\mathbf{1 0}$ & $\mathbf{2 0 2 0}$ & $\mathbf{6}$ & $\mathbf{2 6 . 5 0 7 . 4 1 6 . 1 2 6}$ \\
$\mathbf{1 1}$ & $\mathbf{2 0 2 1}$ & $\mathbf{7}$ & $\mathbf{2 8 . 6 4 5 . 3 4 6 . 8 5 7}$ \\
$\mathbf{1 2}$ & $\mathbf{2 0 2 2}$ & $\mathbf{8}$ & $\mathbf{3 0 . 7 8 3 . 2 7 7 . 5 8 7}$ \\
$\mathbf{1 3}$ & $\mathbf{2 0 2 3}$ & $\mathbf{9}$ & $\mathbf{3 2 . 9 2 1 . 2 0 8 . 3 1 8}$ \\
$\mathbf{1 4}$ & $\mathbf{2 0 2 4}$ & $\mathbf{1 0}$ & $\mathbf{3 5 . 0 5 9 . 1 3 9 . 0 4 9}$ \\
\hline
\end{tabular}

Sumber : Data Diolah, 2018

\section{Pembahasan}

Hasil analisis kontribusi pada penelitian ini menunjukkan kontribusi sektor pariwisata terhadap Pendapatan Asli Daerah yang setiap tahunnya mengalami fluktuatif, meskipun setiap tahunnya pendapatan dari sektor pariwisata selalu mengalami peningkatan. Pada tahun 2011 kontribusi sektor pariwisata terhadap PAD Kabupaten Jember sebesar 3,96 \%. Kontribusi pada tahun 2011 ini adalah kontribusi terbesar yang diberikan oleh sektor pariwisata terhadap PAD Kabupaten Jember selama kurun waktu 7 tahun terakhir yaitu dari tahun 2011 sampai dengan tahun 2017. Kontribusi terbesar ini disebabkan karena pendapatan sektor pariwisata dari penerimaan retribusi tempat parkir khusus cukup besar serta kecilnya peningkatan penerimaan sektor-sektor PAD lainnya yang sah dibandingkan dengan tahun sebelumnya (Bapeda Kabupaten Jember, 2011).

Tahun 2012 kontribusi sektor pariwisata terhadap PAD turun sekitar 0,24\% menjadi 3,72\%. Namun jika dilihat dari jumlah total pendapatan sektor pariwisata pada tahun 2012 ini mengalami kenaikan dari tahun sebelumnya. Penurunan kontribusi ini disebabkan karena peningkatan pendapatan dari sumber-sumber PAD lainnya, sehingga menyebabkan kontribusi sektor pariwisata menurun. Pada tahun 2013 kontribusi sektor pariwisata mengelami kenaikan sebesar $0,03 \%$ menjadi 3,75\%. Kenaikan kontribusi ini disebabkan karena penerimaan dari subsektor hotel dan retribusi tempat penginapan mengalami peningkatan. Tahun 2014 kontribusi sektor pariwisata mengalami penurunan sebesar $0,49 \%$. Jika dilihat dari jumlah pendapatan dari sektor pariwisata seharusnya kontribusi sektor pariwisata terhadap PAD ini mengalami kenaikan, namun malah sebaliknya. Penurunan kontribusi ini disebabkan karena jumlah penerimaan dari sumber-sumber PAD lainnya mengelami kenaikan yang besar seperti dari pajak dan retribusi daerah. Pada tahun 2015 kontribusi sektor pariwisata kembali menurun sebesar $0,11 \%$ menjadi 3,15\%. Sama seperti sebelumnya, pendapatan sektor pariwisata sendiri mengalami kenaikan namun kontribusinya menurun. Penurunan kontribusi ini juga disebabkan karena kenaikan dari penerimaan sumber-sumber PAD yang sah dibandingkan dengan tahun 
sebelumnya.

Pada tahun 2016 kontribusi sektor pariwisata terhadap PAD Kabupaten Jember mengalami kenaikan sebesar $0,26 \%$ menjadi 3,41\%. Kenaikan ini disebabkan karena total penerimaan sektor pariwisata meningkat sebesar 3 miliar dibandingkan dengan tahun sebelumnya serta disebabkan karena peningkatan penerimaan dari sumber-sumber PAD lainnya tidak teralu besar. Sedangkan pada tahun 2017 kontribusi kembali menurun sebesar 0,54\% menjadi 2,87\%. Pada tahun 2017 ini adalah kontribusi terendah yang diberikan oleh sektor pariwisata terhadap PAD Kabupaten Jember. Total pendapatan sektor pariwisata sendiri mengalami kenaikan dibandingkan tahun sebelumnya yaitu sebesar 3,1 miliar. Namun yang terjadi kontribusi sektor pariwisata menurun pada tahun ini. Penurunan ini disebabkan karena peningkatan penerimaan dari sumber Lain-Lain Pendapatan Daerah yang Sah yang sangat tinggi, sehingga menyebabkan kontribusi sektor pariwisata sangat kecil meskipun total pendapatan dari sektor pariwisata sendiri mengalami kenaikan dibandingkan dengan tahun sebelumnya.

Hasil analisi kontribusi diatas menunjukkan bahwa meskipun total penerimaan dari sektor pariwisata setiap tahunnya mengalami kenaikan, namun belum tentu kontribusinya akan mengalami kenaikan pula. Hal ini dapat disebabkan karena penurunan dari total pendapatan sektor pariwisata itu sendiri atau peningkatan dari sumber-sumber PAD lainnya yang lebih besar dibandingkan dengan sektor pariwisata tersebut. Pendapatan total sektor pariwisata Kabupaten Jember memang selalu mengalami kenaikan, namun dilain sisi masih ada beberapa pendapatan subsektor yang mengalami penurunan atau bahkan tidak mendapatkan pendapatan sama sekali. Hal tersebut sangat berpengaruh terhadap kontribusi yang akan diberikan nantinya. Hasil analisis kontribusi juga menunjukkan bahwa kontribusi sektor pariwisata terhadap Pendapatan Asli Daerah Kabupaten Jember selama kurun waktu 7 tahun yaitu dari tahun 2011-2017 masih dikatakan sangat kurang, kontribusinya hanya berkisar antara 2,87\% - 3,96\%. Dikatakan sangat kurang karena kontribusi masih dibawah $10 \%$, hal ini sesuai dengan klasifikasi kriteria kontribusi yang dikeluarkan oleh Depdagri, Kemendagri No. 690.900.327 dalam Abdul Halim (2008:233), jika kontribusi berkisar antara 0-10\%, kontribusi tersebut dikatakan sangat kurang.

Analisis selanjutnya yaitu mengenai analisis trend yang digunakan untuk melihat trend pendapatan dan ramalan pendapatan di tahun-tahun selanjutnya. Hasil analisis data menunjukkan trend pendapatan pada tahun 2011 sebesar 7,27 miliar dan pada tahun terakhir yaitu 2017 trend pendapatan sektor pariwisata Kabupaten Jember sebesar 20,09 miliar. Untuk trend kedepannya, pendapatan dari Sektor Pariwisata Kabupaten Jember akan terus mengalami peningkatan. Ramalan pendapatan pada tahun 2018 sekitar 22,23 miliar dan pada tahun 2024 ramalan pendapatannya sebesar 35,06 miliar

Hasil analisis trend ini menunjukkan bahwa trend pendapatan sektor pariwisata Kabupaten Jember termasuk trend positif. Hal tersebut sesuai dengan teori yang dikemukakan oleh Maryati (2010), jika rata-rata perubahan bertambah maka trend tersebut adalah trend positif, begitupula sebaliknya jika rata-rata perubahan berkurang maka trend tersebut adalah trend negatif atau trend yang mempunyai kecenderungan menurun.

Ramalan pendapatan dari sektor pariwisata di Kabupaten Jember akan terus meningkat pada tahun-tahun selanjutnya. Ramalan pendapatan ini adalah sebagai acuan untuk melihat seberapa besar pendapatan sektor pariwisata, yang nantinya akan berkontribusi terhadap PAD Kabupaten Jember. Hal tersebut akan berpengaruh positif jika pengelolaan sektor pariwisata di Kabupaten Jember terus dikembangkan.

\section{PENUTUP}

Berdasarkan hasil penelitian dan pembahasan mengenai kontribusi sektor pariwisata terhadap Pendapatan Asli Daerah Kabupaten Jember tahun 2011-2017 dapat disimpulkan bahwa kontribusi sektor pariwisata terhadap PAD setiap tahunnya mengalami fluktuatif, meskipun setiap tahunnya pendapatan dari sektor pariwisata selalu mengalami peningkatan. Kontribusi terbesar terdapat pada tahun 2011 yaitu sebesar 3,96\%. Kontribusi terbesar ini disebabkan karena pendapatan dari sektor pariwisata cukup besar serta kecilnya peningkatan penerimaan sektor-sektor PAD lainnya yang sah dibandingkan dengan tahun sebelumnya. Sedangkan kontribusi terendah terdapat pada tahun 2017 yaitu sebesar 2,87\%. Penurunan kontribusi tersebut diakibatkan karena kenaikan jumlah PAD Kabupaten Jember dari sektor-sektor lain dengan jumlah yang lebih besar seperti Pendapatan Badan Layanan Umum (BLUD) dan sumber-sumber PAD lain-lain yang sah. Sedangkan untuk analisis trend menunjukkan bahwa ramalan pendapatan pada tahun-tahun selanjutnya akan terus meningkat. Ramalan 
pendapatan sektor pariwisata Kabupaten Jember pada tahun 2018 sekitar 24,6 M dan akan terus meningkat di tahun-tahun berikutnya.

Berdasarkan kesimpulan diatas, maka penulis memberikan saran kepada Pemerintah Daerah khususnya Dinas Pariwisata dan Kebudayaan Kabupaten Jember untuk mengelola objek wisata lebih profesional lagi dan membangun fasilitas pendukung seperti infrakstruktur jalan dan pengadaan fasilitas lainnya di tempat objek wisata supaya wisatawan lebih tertarik untuk berkunjung. Selain itu Pemerintah Daerah juga harus meningkatkan koordinasi dengan dinas terkait agar pendapatan dari sektor pariwisata dapat dioptimalkan.

\section{DAFTAR PUSTAKA}

Adisasmita, R. 2011. Pengelolaan Pendapatan dan Anggaran Daerah. Yogyakarta: Graha Ilmu.

Frisdiantara. 2016. Ekonomi Pembangunan sebuah Kajian Teoritis dan Empiris. Malang: Universitas Kanjuruhan Malang

Kartajaya H. Sapta Nirwandar. 2013. Tourism Marketing 3.0. Jakarta. Gramedia Pustaka Utama

Sulaiman. 2013. Pengantar Statistik Pariwisata. Bandung. Alfabeta

Sumanto. 2014. Statistik Deskriptif. Yogyakarta : CAPS (Centre of Academic Publishing Service).

Wardiyanta. 2006. Metode Penelitian Pariwisata. Yogyakarta. Andi Offset.

Widyastuti, N.K,. D. Waruwu,. I. K. Suartana. 2017. Pariwisata Spiritual Daya Tarik Wisata Palasari Bali. Denpasar: Pustaka Larasan. 